\title{
Kvantifikace rýhové eroze bezkontaktními metodami
}

\section{RADEK BACHAN}

Klíčová slova: bezkontaktní mapování - bezpilotní letecký systém - kvantifikace eroze -

letecká fotogrammetrie - vodní eroze - přívalové srážky

\section{SOUHRN}

S překotným vývojem v oblasti geoinformačních a komunikačních technologiî se objevují nové možnosti mapování a kvantifikace erozních procesů způsobených př́valovými srážkami. Pro získání relevantních výsledků je důležitá kvalita, hustota a rozsah vstupních dat. Rychlý a poměrně levný sběr přesných geodat umožňují bezpilotní letecké prostředky (UAV - z anglického Unmanned Aerial Vehicle). S využitím metod digitální fotogrammetrie je možné z pořizených leteckých snímků rekonstruovat morfologii terénu odpovídající času měření. Vybraná lokalita zasažená výraznou rýhovou erozí byla v monitorovací kampani nasnímána bezpilotním leteckým systémem složeným z hexakoptéry TAROT 690 a fotoaparátu Sony Alpha 6000. Pro následné polohopisné a výškopisné určení digitálního modelu povrchu (DMP) byly prístrojem GNSS rover Trimble R2 zaměřeny pozemní kontrolní body (GCP - z anglického Ground Control Points). Celkový objem erodované půdy byl stanoven na $4274 \mathrm{~m}^{3}$. Odchylky kontrolních bodů se pohybovaly v prvních jednotkách centimetrů. Studie popisuje prípravu a práci v terénu, bezkontaktní mapování zájmového území, zpracování získaných dat a výsledný výpočet a kvantifikaci objemu odneseného materiálu ze zemědělského pozemku poškozeného erozí.

\section{ÚVOD}

Orná půda je v posledních letech častěji vystavována povětrnostním extrémům, jako jsou dlouhá suchá období a přivalové srážky. A právě př́ivalové srážky jsou velmi často spouštěčem plošné a rýhové vodní eroze [1]. Míru rizika vzniku eroze dále umocňuje vysoký sklon svahu, faktor nepřerušené délky svahu, chybějící vegetační kryt nebo nevhodně zvolený osevní postup [2]. Důsledkem je odnos nejúrodnějších půdních horizontů ze zemědělského pozemku, snižování obsahu organické hmoty, minerálních živin a humusu $v$ půdě, poškození pěstovaných rostlin nebo smyv osiva a sadby [3, 4]. Sekundárním důsledkem erozního smyvu je transport splavenin a zanášení vodních toků a vodních nádrží erodovaným materiálem [5]. Erozní procesy tak mají negativní vliv na produkční schopnosti orné pưdy a přinášejí celou řadu problémů také vodnímu hospodářství. Vlivem eroze na zemědělskou půdu a její ochranou se ve své práci podrobně zabývá napríklad Janeček a kol. [6].

Pro stanovení erozní ohroženosti půdy byly $\vee$ minulosti vyvinuty modely založené na empirických metodách. Mezi nejpoužívanější patří univerzální rovnice ztráty půdy (USLE) [7] nebo distributivní model erozních a transportních procesů WaTEM/SEDEM [8]. Existují také modely založené na fyzikálních metodách, které charakterizují průběh erozních a transportních procesů na základě fyzikálních vztahů a závislostí. Tyto modely jsou velmi náročné na vstupní data a výpočetní techniku. Rozdělení a přehled metod a modelů erozní ohroženosti popisuje např́klad Merritt a kol. [9]. Na základě zmíněných modelů vymezil Novotný a kol. pro území České republiky téměř 50 \% plochy orné půdy jako ohrožené vodní erozí [2]. Z pohledu celé kontinentální Evropy pak Panagos a kol. určil průměrnou ztrátu orné půdy na 2,46 t/ha/rok [10]. Existující modely tohoto typu dobře slouží pro odhad prưměrné ztráty pưdy a dokážou lokalizovat zemědělskou půdu ohroženou erozí.

V článku popisovaná případová studie se naproti tomu zabývá monitoringem již proběhlé erozní události a kvantifikací objemových ztrát orné půdy na konkrétním zemědělském pozemku.

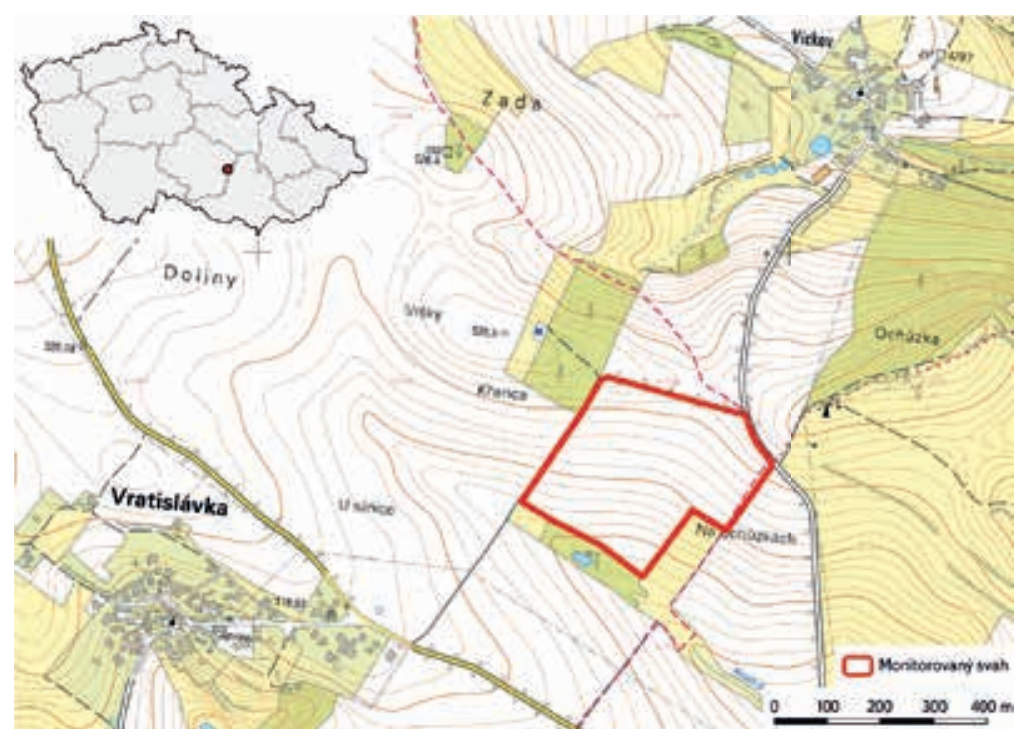

Obr. 1. Lokalizace erozí poškozeného svahu

Fig. 1. Localisation of the slope damaged by erosion

Pro mapování rýhové eroze se v minulosti využívaly kontaktní metody [11]. $\checkmark$ posledních letech pak do popredí vstupují metody bezkontaktní, mezi které patří například družicové snímkování, letecké snímkování a snímkování pomocí UAV. Družicové a letecké snímky jsou vhodné spíše pro lokalizaci erozní události, nedosahují totiž rozlišení potřebného pro detailní vyhodnocení a kvantifikaci eroze [12]. Naproti tomu systémy UAV umožňují mapovat zemský povrch z velmi nízkých letových hladin, a získat tak spojitou informaci o aktuálním stavu monitorovaného území ve velmi vysokém rozlišení. V terénu získaná data Ize pomocí fotogrammetrických metod převést do podoby podrobných ortofotomap nebo detailních digitálních modelů povrchu, nad nimiž Ize následně 
počítat mapová algebra. Hojně používanou fotogrammetrickou metodou, využitou i pro prezentovanou prípadovou studii, je Structure from Motion (SfM), která na základě dvojrozměrných obrazových sekvencí dokáže v digitálním prostředí rekonstruovat trojrozměrné prostorové struktury [13]. Přesností metody SfM v souvislosti s výškou, z níž byly snímky pořizeny, se zabývá Smith a kol. Dokládá lineární závislost mezi vzrůstající letovou hladinou a chybovostí konečného výsledku [14]. Záznamem a měřením eroze s využitím UAV se ve svých pracích zabývali napríklad Carollo a kol. nebo Peter a kol. [15, 16]. Postupy prímého monitoringu a kvantifikace erozních jevů pomocí digitální fotogrammetrie představuje také Žižala a kol. [12].

Článek přináší výsledky prípadové studie usilující o co možná nejpřesnější určení objemu odneseného materiálu ze svahu zasaženého erozí s využitím bezkontaktních metod. Záznam rýhové eroze byl pořízen pomocí UAV systému a k vyhodnocení erozního smyvu sloužil software Agisoft PhotoScan Professional a ESRI ArcGIS. Díky použitým metodám a technologiím bylo možné sestrojit podrobný digitální model povrchu (DMP), který reflektuje stav monitorovaného svahu v době měření. DMP nese požadovanou informaci o morfologii terénu a je možné nad ním odvodit metriku erozních rýh. Při aplikaci optimálního postupu pak Ize kvantifikovat množství erodovaného materiálu.

\section{METODIKA SBĚRU DAT, PŘÍPRAVA A PRŮBĚH MĚŘENÍ}

\section{Pilotní lokalita}

Monitorovaný svah se nachází v katastrálním území obce Vratislávka v severní části Jihomoravského kraje (obr. 1). Jedná se o zemědělsky využívaný pozemek obdélníkového tvaru shora ohraničený místní asfaltovou komunikací a ve spodní části remízkem s korytem a břehy Kozlího potoka. Dominantním pưdním typem jsou kambizemě [17]. Celková plocha svahu zasaženého erozí je 9,5 ha a sklon se pohybuje $v$ rozmezí $3-7^{\circ}$, tj. kategorie mírný sklon. Míru eroze umocňuje faktor nepřerušené délky svahu, na zemědělském pozemku není aplikováno žádné protierozní opatření. Nadmořská výška pozemku se pohybuje v intervalu 495-523 m n. m. Přibližně polovina svahu je dle monitoringu VúMOP zařazena mezi mírně erozně ohrožené půdy [17].

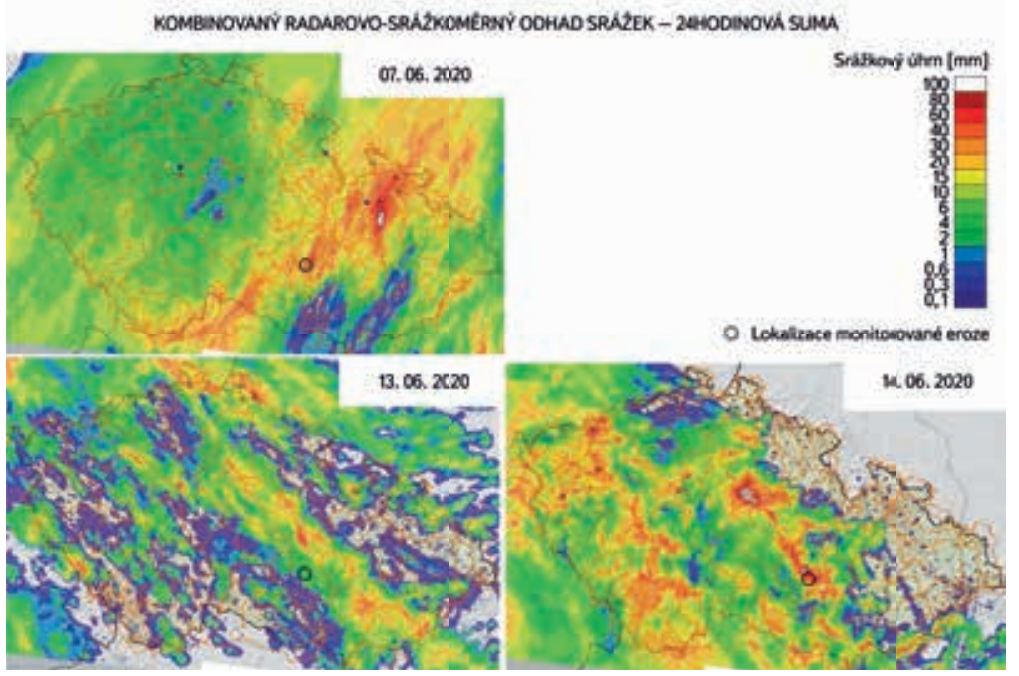

Obr. 2. Denní srážkové úhrny a lokalizace monitorovaného svahu Fig. 2. Daily rainfall totals and localisation of the monitored slope
Spouštěčem hodnocené rýhové eroze byly opakované prívalové srážky ze 7., 13. a 14. června 2020 (obr. 2), kdy dle dat Českého hydrometeorologického ústavu na monitorovaný zemědělský pozemek spadlo v průběhu 24 hodin 42 mm srážek (7. června), 9 mm srážek (13. června), respektive 57 mm srážek (14. června). První a druhá srážková epizoda nasytila půdu vodou a narušila soudržnost a integritu svrchní vrstvy půdního horizontu. Př́valová srážka ze dne 14. června pak spadla na částečně rozrušenou pưdní strukturu s výrazně sníženou infiltrační schopností. Původně plošný odtok se postupně soustředil do půdních zářezů, které se ve střední části svahu spojily a vytvořily znatelné erozní rýhy (obr. 3). Orná půda na monitorovaném svahu byla v době nástupu príčcinných srážek bez vegetačního krytu, což vedlo $k$ akceleraci eroze. $V$ době měření zemědělský pozemek pokrýval výdrol. Okolní svahy kryté vegetací byly bez známek erozního poškození, a to i přes jejich vyšší sklonitost.

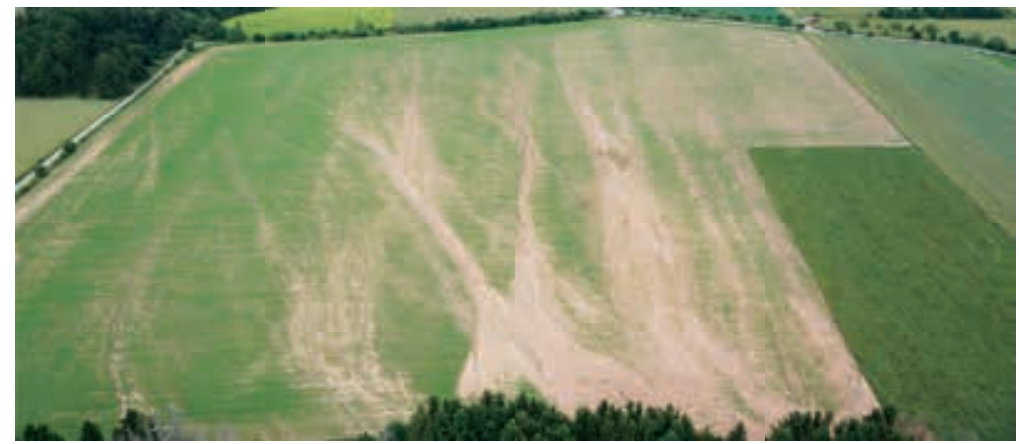

Obr. 3. Letecký snímek monitorovaného svahu

Fig. 3. Aerial image of the monitored slope

\section{MĚŘICÍ APARATURA, SOFTWAROVÉ VYBAVENÍ}

\section{UAV systém}

Hexakoptéra TAROT 690 byla navržena pro bezkontaktní sběr dat pomocí leteckého snímkování (obr. 4). Stroj disponuje vysokovýkonným hardwarovým vybavením, ř́zen může být manuálně i automaticky. Kevlarová konstrukce bezpilotního letadla je osazena kompletním letovým řídicím systémem DJ A2, který je sestaven z inerciální jednotky IMU (Inertial Measurement Unit) vybavené barometrickým senzorem pro měření výšky letu, GPS kompasem, signalizačním bluetooth modulem, napájecí jednotkou a regulátory pro ovládání motorů hexakoptéry. Na základě údajů z IMU a GPS rídicí jednotka ovládá bezpilotní letadlo a zajištuje automatickou stabilizaci náklonu a výšky letu. Pod hexakoptéru je zavěšen gyroskopicky stabilizovaný výkyvný držák, který nese snímací zařízení - v tomto prípadě digitální fotoaparát SONY Alpha 6000. Fotoaparát disponuje 24 Mpx CMOS snímačem a hybridním systémem fázového ostření. Je tak schopný pořizovat snímky ve vysoké kvalitě a rozlišení i za složitých povětrnostních podmínek [18].

\section{Trimble R2}

GNSS přijímač Trimble R2 slouží ke kvalitnímu, rychlému a pohodlnému sběru presných geoprostorových dat (obr. 4). Dvoufrekvenční GNSS přijímač využívá nejen signály ze všech stávajících i budovaných družicových systémů (GPS, GLONASS, Galileo, BeiDou atd.), ale také externí korekce různých zdrojů. Přístroj je vybaven čipem Trimble Maxwell 6 s 220 kanály pro maximální výkon, spolehlivost a přesnost měěení v reálném čase. Měřicí souprava využívá korekce 
z tradičních RTK a VRS sítí a umožňuje sběr geoprostorových dat s centimetrovou přesností v horizontálním i vertikálním směru. Odolná konstrukce přijímače dovoluje práci $v$ nejnáročnějších podmínkách a díky technologii Floodlight i v částečně zastíněném prostředí. Kompaktní hardwarové vybavení je doplněno sofistikovaným softwarem Trimble ACCESS [19].

\section{Agisoft PhotoScan Professional}

Pro zpracování získaných leteckých snímků byl využit profesionální software Agisoft PhotoScan Professional. Jedná se o samostatný fotogrammetrický software určený k automatickému generování bodových mračen, polygonálních modelư, georeferencovaných ortofotomap a digitálních a výškových modelů ve vysokém rozlišení. Software využivá moderní technologie a metody digitální fotogrammetrie k rekonstrukci snímaných 3D povrchů na podkladě získaných fotografií. Dílči i konečný výsledek analýz a výpočtů Ize v různých formátech vyexportovat pro další zpracování v geografických informačních systémech (GIS) [13].

\section{ESRI ArcGIS}

Pro detailní analýzu snímaného území a vytvořeného 3D modelu povrchu byl použit geografický informační systém ESRI ArcGIS určený pro práci s prostorovými daty. $V$ rozhraní ArcMap je možné geodata podrobně analyzovat, editovat nebo nad nimi počítat matematické funkce [20]. Software sloužil zejména ke stanovení celkového objemu erozních rýh a vizualizaci erozního poškození monitorovaného svahu.

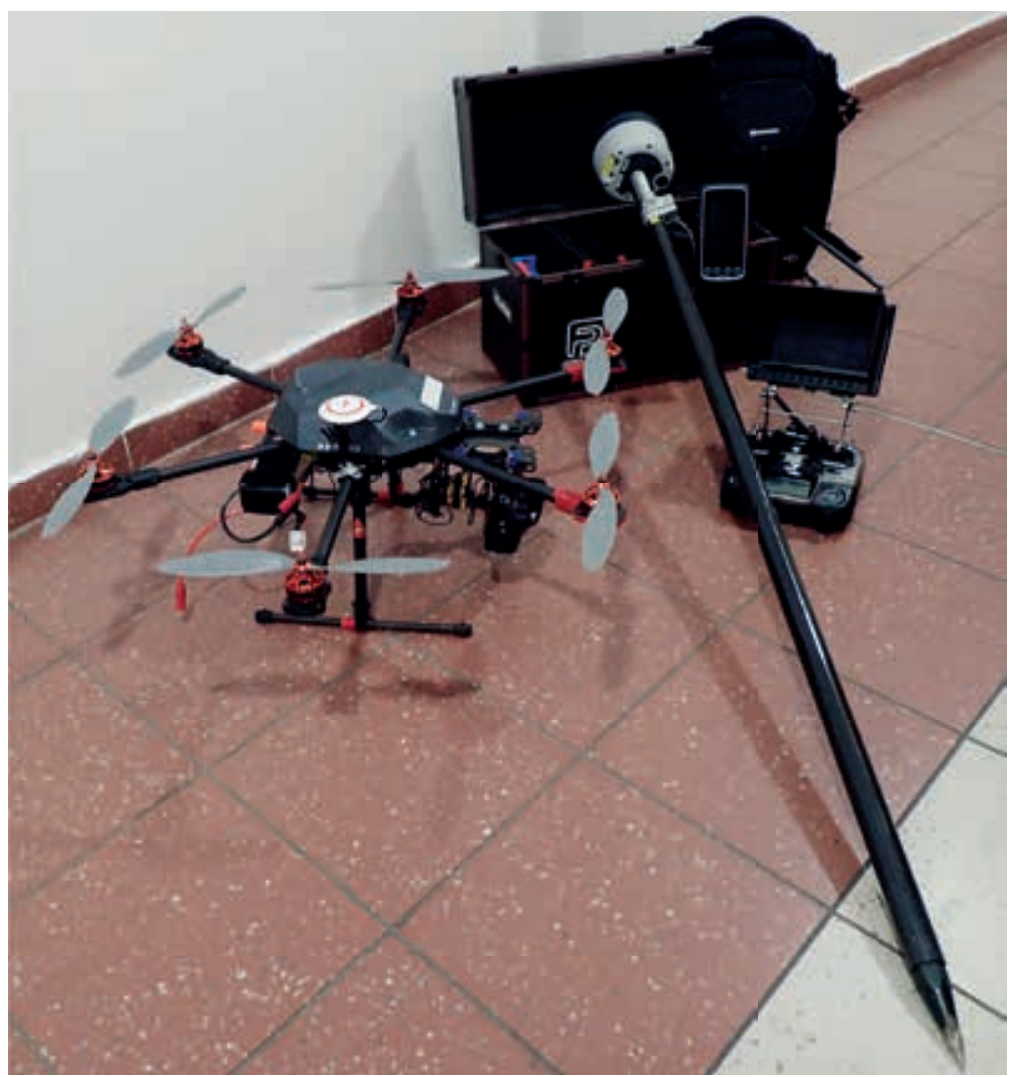

Obr. 4. Měřicí aparatura použitá pro snímkování monitorovaného svahu - UAV a GNSS prijímač Trimble R2

Fig. 4. Measuring devices used for capturing the monitored slope - UAV and Trimble R2 GNSS receiver

\section{TERÉNNÍ MĚŘENÍ A POUŽITÉ METODY}

Vlastní zaměření erozní situace proběhlo 23. června 2020 v př́iznivých povětrnostních podmínkách. V lokalitě převládala polojasná obloha, bezvětří a teploty mezi $23-26^{\circ} \mathrm{C}$. Tyto podmínky byly pro práci s bezpilotním letadlem ideální, polojasná obloha přispěla ke kvalitě získaných fotografií a díky bezvětří $\checkmark$ kombinaci s teplotou byla maximalizována doba letu stroje.

Po prvotním terénním průzkumu monitorovaného svahu byla ve vztahu k předpokládanému letovému času (čtyři plně nabité LiPo akumulátory) stanovena výška letu na 25 m nad terénem. Takto zvolená letová hladina umožnila zaměřit približně třetinu zasaženého území při vysoké kvalitě a přesnosti získaných dat. Pro zaměření celého svahu při dostatečném překryvu jednotlivých snímků by letová výška musela být více než dvojnásobná. Pořizené snímky by měly nižší rozlišení, a to by vedlo k shlazení terénu, problémové identifikaci terénních hran a zlomů - došlo by ke snížení korektnosti výsledného digitálního modelu povrchu.

Před samotným vzletem bezpilotního letadla bylo nutné vybavit monitorované území pozemními kontrolními body (GCP - Ground Control Points). Pomocí zařizení Trimble R2 bylo zaměřeno 32 GCP, pro které byly získány přesné $X, Y, Z$ souřadnice, kde Z je nadmořská výška ve výškovém referenčním systému Balt po vyrovnání (Bpv). Polohopisná a výškopisná datová sada byla v dalších krocích využita k určení geometrie a georeferencování digitálního modelu povrchu a efektivnějšímu spojení pořizených snímkủ.

$\checkmark$ prostoru zasaženého svahu bylo mimo náhodně rozmístěných GCP zaměřeno dalších 90 pozemních bodů nevstupujících do výpočtu digitálního modelu povrchu. $X, Y, Z$ souřadnice pro tyto body byly získány ve třech liniích ( $v$ horní, střední a dolní části svahu), kolmých na erozní rýhy. Cílem bylo vytvorit kontrolní řez terénem pro následné porovnání charakteristik erozních rýh a DMP a určení odchylek nadmořské výšky pro jednotlivé body. Zaměření bodů proběhlo s využitím zařízení Trimble R2 a měřicího pásma v cca dvaceticentimetrovém kroku s větší hustotou uvnitř erozních zářezů. Celková délka každého jednotlivého řezu terénem se rovnala pěti metrům.

Bezkontaktní sběr dat pomocí bezpilotního systému proběhl na principu snímkování erozí poškozeného svahu z předem určené letové hladiny. Aby bylo možné jednotlivé snímky bez problémů spojit a následně vytvořit kompletní DMP, při pořizování fotografií bylo nutné dosáhnout 60-80\% překryvu. Na základě výšky letu, potřebného překryvu fotografií a požadované kvality snímků byla určena rychlost pohybu hexakoptéry TAROT 690 a frekvence záznamu povrchu pomocí digitálního fotoaparátu SONY Alpha 6000 připevněného k bezpilotnímu letadlu. Operátor pomocí pozemní ovládací stanice udržoval rychlost letu hexakoptéry v rozmezí $2,5-3,0 \mathrm{~m} / \mathrm{s}$ a frekvenci fotografování 20 snímků/min. Pro záznam cca 2,6 ha poškozeného pozemku bylo pořízeno 1756 fotografií za využití čtyř plně nabitých LiPo akumulátorů, celkový letový čas byl přibližně 47 minut.

\section{Zpracování dat}

V terénu získaná data $\vee$ podobě leteckých snímků a zaměřených GCP byla $\checkmark$ několika krocích zpracována $v$ softwarovém prostředí Agisoft PhotoScan Professional. Specializovaný software dokáže metodou Structure from Motion spojit jednotlivé fotografie na základě identifikace společných bodů na překrývajících se snímcích [13]. Výsledkem je řídké bodové mračno a informace o poloze, směru a náklonu fotoaparátu v momentě vzniku fotografie. $V$ dalším kroku jsou pro následné georeferencování modelu lokalizovány GCP se zaměřenými geografickými souřadnicemi. Na základě vypočtených a vložených údajů je vytvořeno husté bodové mračno, které po zvolení souřadnicového systému, v tomto prípadě S-JTSK Křovák East North, umožňuje tvorbu digitálního modelu povrchu a georeferencované ortofotomapy monitorovaného území. Získaná data je možné v rưzných formátech exportovat a využít pro další zpracování v geografických informačních softwarech (obr. 5). 


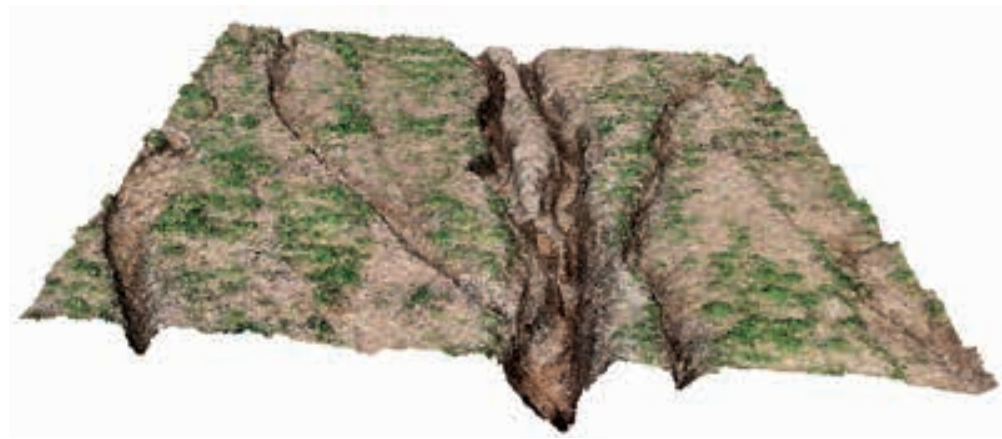

Obr. 5. Ukázka detailu erozní rýhy v softwaru Agisoft PhotoScan Professional Fig. 5. Sample of the erosion rill detail in Agisoft PhotoScan Professional software

Základním vstupem pro stanovení objemu výmolové eroze je digitální model terénu (DMT). Rozlišení modelu přímo ovlivňuje výsledný objem, proto je nutné použít co nejpodrobnější data. Pro určení míry eroze byla z programu Agisoft PhotoScan Professional vyexportována geodatabáze s bodovou třídou prvků popisující polohopisné a výškopisné určení hustého bodového mračna v souřadnicovém systému S-JTSK Křovák East North a výškovém systému Balt po vyrovnání (Bpv). Geodata reprezentující monitorované území byla nahrána do prostředí ESRI ArcGIS, kde byla na jejich základě vytvořena nepravidelná trojúhelníková sít (TIN - Trianguled Irregular Network). Vygenerovaný TIN byl následně převeden na rastrový formát o velikosti pixelu 0,5 cm. Tím vznikl velmi podrobný digitální model povrchu se záznamem rýhové eroze odpovídající času měření

\section{Stanovení objemu erozních rýh}

Pro samotný výpočet objemu erozních rýh bylo nutné vymodelovat co nejpřesnějši teoretický průběh terénu před nástupem eroze. Ke konstrukci původního terénu byl využit vytvořený detailní 3D model poškozeného svahu v kombinaci s georeferencovanou ortofotomapou ve vysokém rozlišení. Nad zmíněnými datovými zdroji byla manuálně identifikována místa nezasažená erozí, sedimentací a nekrytá vegetací. Vzniklo mračno diskrétních bodů, kterému byly z podkladového digitálního modelu povrchu definovány údaje o nadmořské výšce s využitím funkce Extract Values to Points. Ze 4762 nově vzniklých diskrétních bodů byla vytvořena nepravidelná trojúhelníková sît reprezentující původní povrch půdy před nástupem eroze. Aby ho bylo možné lépe porovnávat a provádět matematické operace, byl podklad TIN na rastr o stejné velikosti pixelu jako DMP zaznamenané eroze. Odfiltrováním nadprahových hodnot byl původní DMP očištěn o vegetační kryt - vznikl DMT. Rozdílovou analýzou rastru DMT eroze a DMT teoretického původního povrchu vznikla rastrová vrstva znázorňující rozsah a hloubku erozních zářezů v absolutních hodnotách. Objem erodovaného materiálu na monitorovaném pozemku byl pak odvozen jako násobek plochy a průměrné hodnoty rozdílového rastru vypočtené pomocí zonální statistiky (obr. 6).

\section{VÝSLEDKY}

Na základě rozdílové analýzy zaměřeného DMT a vytvořeného teoretického původního povrchu byl pro monitorovaný svah stanoven objem eroze na $4274 \mathrm{~m}^{3}$. V erozních rýhách a výrazných zářezech došlo při přepočtu na celou plochu pozemku ke smyvu půdního horizontu o průměrné výšce $4,5 \mathrm{~cm}$. Hloubka nejvýraznějších erozních rýh presahovala $85 \mathrm{~cm}$ při šîrce téměř $110 \mathrm{~cm}$. Pro váhové vyjádření odneseného materiálu byla použita objemová hmotnost suché půdy, kterou pro svrchní vrstvu půdy Honzík a kol. uvádí v rozmezí 1,2-1,5t/m³ [21].

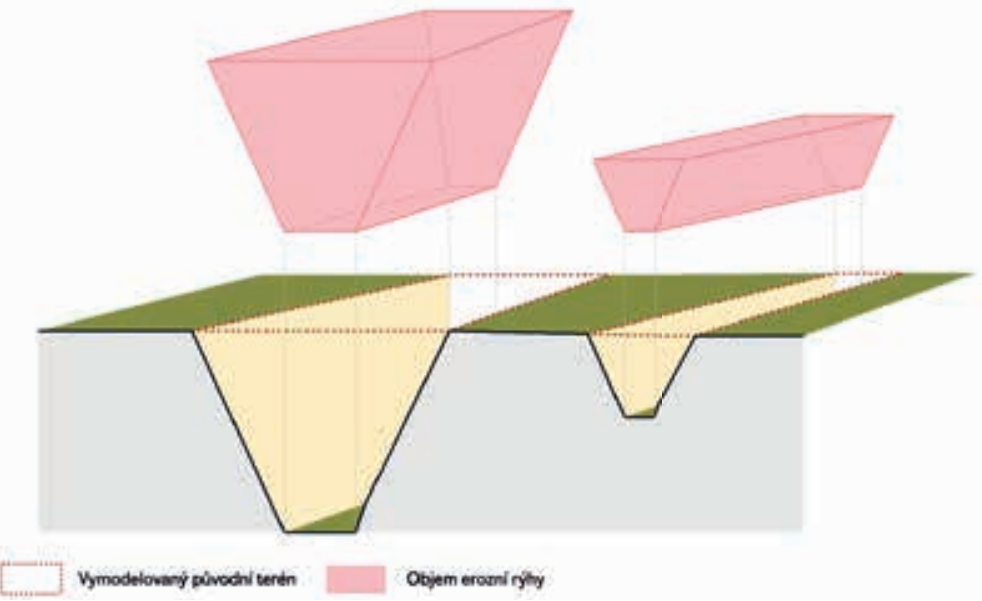

Obr. 6. Schéma výpočtu objemu erozní rýhy

Fig. 6. Scheme of the calculation of the erosion rill volume

Při zvolené objemové hmotnosti na horní hranici zmíněného intervalu se odnos materiálu ze zemědělského pozemku rovná 675 t/ha. V České republice je př́pustná ztráta půdy pro středně hluboké $(30-60 \mathrm{~cm})$ a hluboké půdy (nad $60 \mathrm{~cm}$ ) stanovena na $4 \mathrm{t} / \mathrm{ha} /$ rok [6]. V průběhu jednoho týdne tak prívalové srážky způsobily na monitorovaném svahu 169krát vyšší odnos materiálu, než je stanovená prípustná ztráta. Ortofotosnímek a vizualizace průběhu erozních rýh ve vybrané části svahu jsou znázorněny na obr. 7.

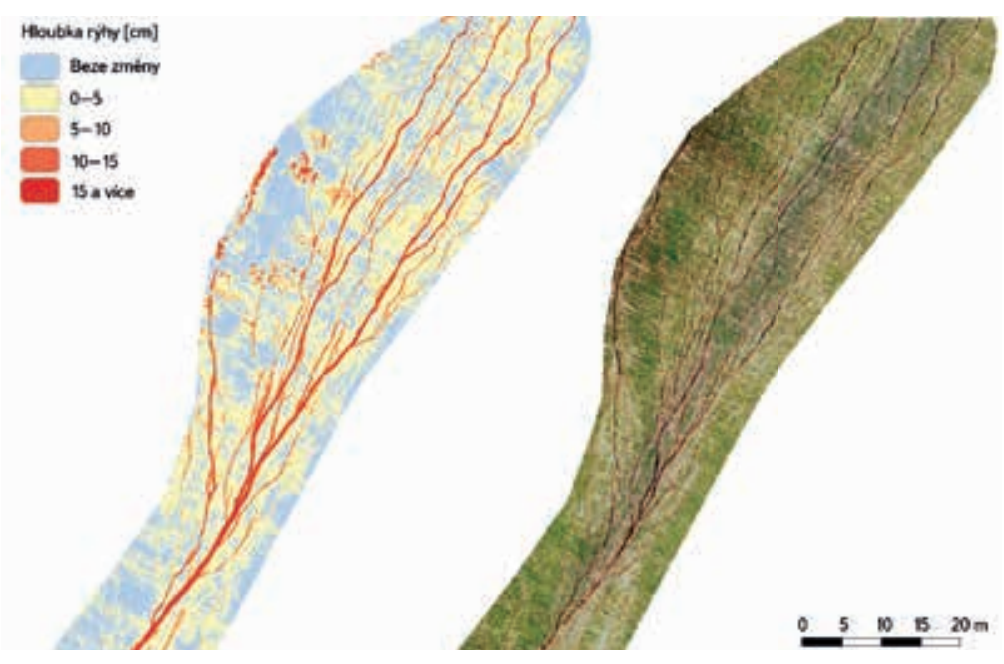

Obr. 7. Vizualizace hloubek erozních rýh ve vybrané části poškozeného svahu (vlevo), ortofotomapa stejné části svahu (vpravo)

Fig. 7. Visualization of the depths of the erosion rills in a selected part of the damaged slope (on the left); ortophotomap of the same part of the slope (on the right)

Z výše uvedeného je patrné, že zemědělský pozemek byl vystaven devastujícím erozním účinkům a byla trvale poškozena úrodnost zasaženého půdního horizontu. Vlastní eroze byla navíc zesílena chybějícím vegetačním krytem $\checkmark$ době príchodu prívalových srážek.

Pro verifikaci vytvořeného digitálního modelu povrchu bylo v terénu nezávisle zaměřeno 90 pozemních bodů. Tyto body umístěné ve formě tří příčných profilů sloužily k analýze výškové přesnosti 3D modelu a nevstupovaly do výpočtu DMP. Průběh terénu vymodelovaný metodami digitální fotogrammetrie s vyznačenými, nezávisle zaměřenými body a ortofotosnímkem vybraného príčného profilu ukazuje obr. 8. 


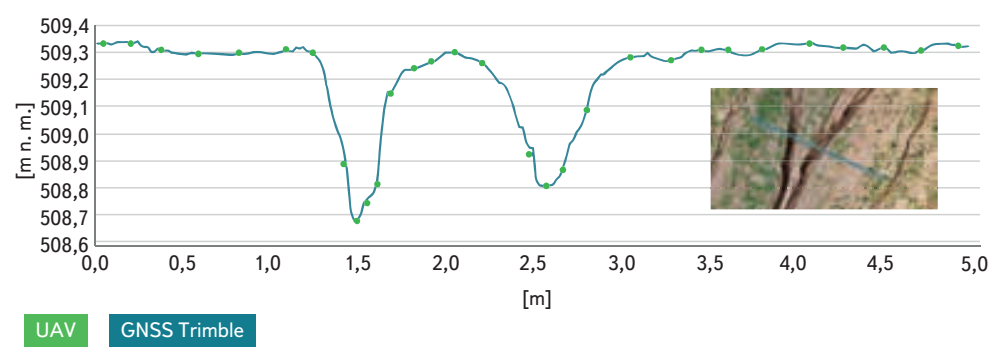

Obr. 8. Průběh terénu vymodelovaný metodami digitální fotogrammetrie (UAV) s vyznačenými, nezávisle zaměřenými body (GNSS Trimble) a ortofotosnímkem vybraného příčného profilu

Fig. 8. Terrain course created by digital photogrammetry methods (UAV) with marked independently captured points (Trimble GNSS) and ortophotograph of a selected cross section

Získaná data byla importována do pracovního prostředí ESRI ArcGIS, v němž byly vypočteny odchylky hodnot nadmořských výšek pro vymodelovaný terén a zaměřené body. Výsledky jsou pro přehlednost vyobrazeny ve formě krabicového grafu na obr. 9. V něm jsou zaměřené body rozděleny do jednotlivých řezů terénem a dále pak dle umístění bodu uvnitř/vně erozní rýhy.

Medián, horní a dolní kvartil odchylek nadmořských výšek se v zaměěených rezech pohyboval v těsné blízkosti nuly. Minimální a maximální hodnoty odchylek pak v řádech desetin centimetru. Výjimkou byl jeden zaměřený bod v blízkosti kolmé stěny velmi hlubokého erozního zářezu. Zde může měření ovlivňovat zastínění při snímkování a možná tendence shlazovat vymodelovaný terén v místech s nižší hustotou pokrytí daty.

Zaměřené body uvnitř erozních zářezů ukazuji spíše na nadhodnocování nadmořské výšky vymodelovaného terénu. Body získané GNSS měřením uvnitř erozních rýh mají odchylku hodnot mediánu, horního a dolního kvartilu v blízkosti úrovně -1 cm. Odchylky nadmořské výšky zaměřených bodů v erozí nezasažené ploše jsou oproti vymodelovanému terénu minimální a pohybují se $\checkmark$ mírně kladných číslech.

Př́čné profily i krabicový graf ukazují silnou korelaci mezi terénem vymodelovaným metodami digitální fotogrammetrie a body zaměěenými pomocí GNSS přijímače Trimble R2. Zjištěné odchylky nadmořských výšek se u většiny bodů pohybují v prvních desetinách centimetru. Výraznější rozdíly v nadmořských výškách jsou patrné pouze u bodů lokalizovaných do erozních zářezů. Zde vymodelovaný terén ukazuje vyšší nadmořské výšky, a může tak podhodnocovat celkovou míru erodovaného materiálu. Nejvyšší hodnoty odchylek byly zaznamenány v blízkosti kolmých stěn erozních zářezů - 3D model terénu má tendenci shlazovat kolmé stěny erozních rýh. V prípadě hlubokých erozních zářezů se záporné odchylky hodnot zaměřených bodů pohybovaly okolo $-2 \mathrm{~cm}, \mathrm{v}$ jednom prípadě záporná odchylka prekeročila $-5 \mathrm{~cm}$. Na podhodnocování objemu eroze a shlazování kolmých stěn erozních rýh u fotogrammetrických metod ve své práci upozorňuje i Glendell a kol. [22]. Těsnost zaměřených bodů a vymodelovaného terénu je vzhledem k velikosti zaznamenané plochy velmi vysoká. 3D model terénu Ize označit za reprezentativní a stanovený objem odneseného materiálu se dá považovat za odpovídající realitě, prípadně lehce podhodnocený.

Př́mo v terénu bylo vizuálně patrné ukládání erodovaného materiálu při patě svahu a v údolnici a korytě Kozlího potoka, odkud bude postupně unášen níže po toku. Ve střednědobém časovém horizontu bude erodovaná zemina sedimentovat v soustavě malých vodních nádrží (MVN) na Kozlím potoku v katastru obce Ždárec (soustava MVN je od monitorovaného svahu vzdálena necelý jeden kilometr). Zanášení vodních nádrží je možné označit za další z negativních důsledků eroze způsobené kombinací nesprávného využívání území a příčinných prívalových srážek.

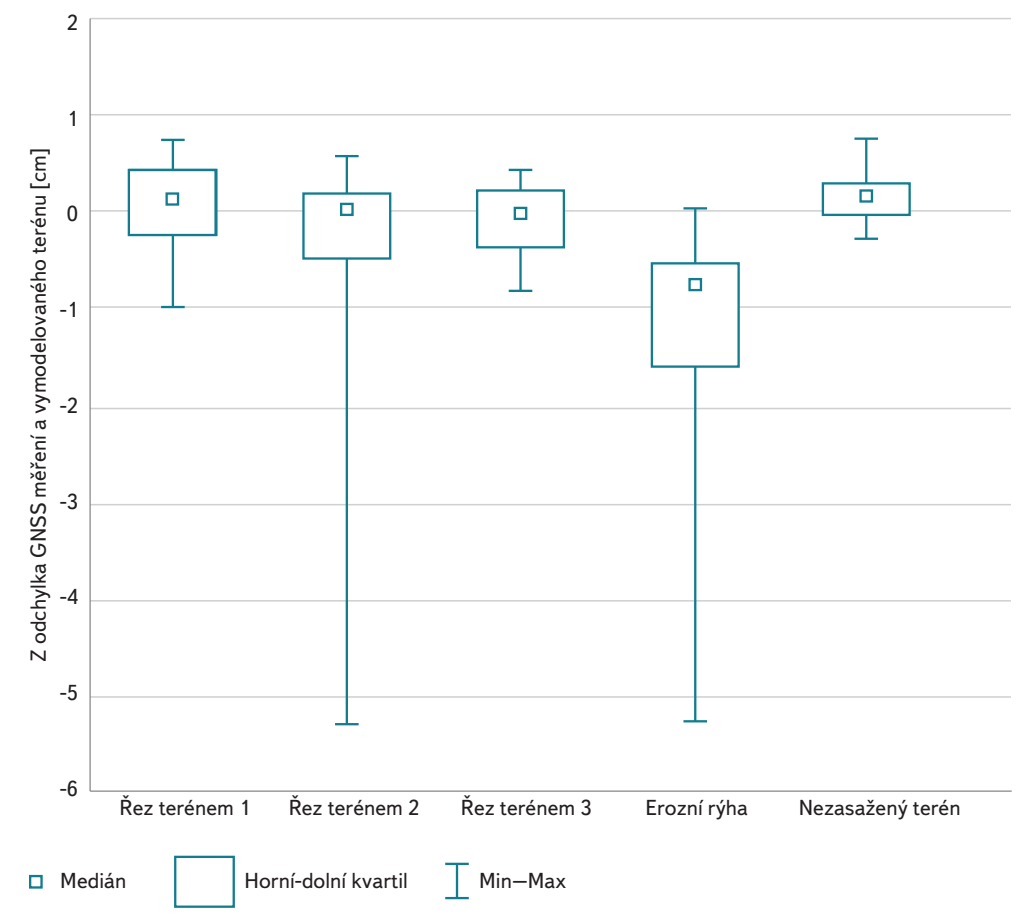

Obr. 9. Krabicový graf Z odchylek GNSS měření a 3D modelu terénu získaného metodami digitální fotogrammetrie

Fig. 9. Box plot from the deviations of GNSS measurement and 3D terrain model obtained by digital photogrammetry methods

\section{DISKUZE}

Pro rekonstrukci reálného digitálního modelu terénu sloužícího k dalším analýzám je zcela zásadní získat co nejpřesnější geodata v maximálním rozsahu a hustotě pokrývající monitorované území. Chyby mohou vznikat při práci v terénu i při následném zpracování dat (postprocessing). Při sběru dat s využitím bezpilotního letadla je nutné dbát na pečlivé zaměěení GCP, dostatečný překryv pořízených snímků a vhodně zvolenou letovou hladinu. Vyšší letová výška zpravidla snižuje rozlišení a korektnost konečného výsledku [23]. S nižší letovou výškou je zachyceno více terénních detailů, naproti tomu klesá rozloha zaznamenaného území a zvyšuje se časová náročnost. Stanovená hodnota objemu odneseného materiálu je ovlivněna také kvalitou rekonstrukce stavu původního povrchu před erozní událostí. Zde mohou vznikat chyby v nesprávné lokalizaci bodů do erozních prohlubní, sedimentačních lavic nebo jinak změněných původních částí svahu. V potaz je nutné vzít i zanedbání plošné eroze. Stanovený objem erodovaného materiálu je tedy spíše mírně podhodnoceným odhadem než definitivním určením skutečnosti.

Skokový vývoj v technologiích bezpilotních leteckých systémů v kombinaci se snižováním jejich finanční náročnosti vede k rychlejšímu, přesnějšímu a bezpečnějšímu sběru dat. V současné době existují UAV vybavené RTK ( $z$ anglického Real-Time Kinematic) systémem a vysoce precizními GNSS moduly pro satelitní pozicování. Takto vybavený stroj dokáže snímat velmi presná RTK data a sledovat a mapovat trajektorii letu dronu s centimetrovou přesností. Ke každému pořízenému snímku jsou k dispozici přesná metadata, která usnadňují následné zpracování a zvyšují korektnost konečného výsledku. Odpadá nutnost použití GCP a snižuje se časová náročnost práce v terénu i možná chybovost výsledného digitálního modelu povrchu. Pořizovací cena UAV strojů vybavených RTK modulem a redundantním GNSS systémem se pohybuje okolo 200 tisíc Kč a v konečném důsledku takto vybavené drony zefektivňují práci v terénu a zpřesňují a zrychlují i následný postprocessing nasbíraných dat [24]. 


\section{ZÁVĚR}

Provedená monitorovací mise je součástí dlouhodobého sledování erozních událostí a dalších následků přívalových srážek brněnskou pobočkou VúV TGM s cílem získat datovou základnu pro detailní analýzy príčin a důsledků spojených s přívalovými srážkami. Primárním cílem mapování erozního poškození bylo stanovení co nejpřesnějšího odhadu objemu eroze s využitím bezkontaktních metod měření. Dalším cílem bylo ověření korektnosti 3D modelu konstruovaného pomocí leteckého snímkování a metod Structure from Motion $\checkmark$ porovnání s nezávisle zaměřenými kontrolními body.

Získaná data ukazují výraznou korelaci, odchylka naměřených nadmořských výšek se pohybuje v rádech desetin centimetru. Potvrzená vysoká přesnost bezkontaktních metod při modelování terénu je předurčuje k širšímu využití nejen v oblasti hodnocení erozních situací. Při vhodně zvolené letové hladině je dosaženo vysoké hustoty pokrytí daty, a tím je minimalizován následný vliv interpolace do spojitého digitálního modelu terénu. Další výhodou je vysoká operabilita bezpilotních letadel. Za nevýhody Ize označit silnou závislost UAV na povětrnostních podmínkách, subjektivitu při stanovení původního terénu před přivalovou srážkou a možné shlazování kolmých stěn erozních zářezů, čímž dochází k podhodnocování skutečného objemu erozního odnosu.

Data nasbíraná UAV systémem a zpracovaná metodami digitální fotogrammetrie poskytují vysoce kvalitní zdroj informací využitelný nejen v geografických informačních systémech. Popsané postupy odhadu míry eroze jsou jednou z možností využití takto získaných geodat. Představené postupy Ize označit za efektivní a výsledné hodnoty objemu eroze za reálné.

\section{Poděkování}

Př́spěvek vznikl za podpory projektu CZ.071.02/0.0/0.0/16_040/0000382 "Rekreační potenciál vody v Praze - stav a výhledy" rešeného $v$ rámci operačního programu Praha-pól růstu.

\section{Literatura}

[1] KRÁSA, J. Empirické modely vodni erozev Čr. Praha: ČVUT, 2010, $159 \mathrm{~s}$

[2] NOVOTNÝ, I. a kol. Príručka ochrany proti vodní erozi. Praha: Ministerstvo zemědělství, 2014, 73 s. ISBN 978-80-87361-33-7.

[3] VOPRAVIL, J., KHEL, T., HAVELKOVÁ, L., BATYSTA, M. Studie zabývajícíse základní problematikou eroze půdy a jejím současným stavem v Ústeckém a Jihomoravském kraji České republiky. Praha: SOWAC, 2013, $51 \mathrm{~s}$.

[4] LAL, R. Soil degradation by erosion. Land Degradation \& Development, 2001, 12, p. 519-539

[5] BORRELLI, P., MÄRKER, M., PANAGOS, P., SCHÜTT, B. Modeling soil erosion and river sediment yield for an intermountain drainage basin of the Central Apennines. Catena, 2014, 114, p. 45-58

[6] JANEČEK, M. a kol. Ochrana zemědělsképưdy pred erozi. Praha: ISV, 2012, 108 s. ISBN 978-80-87415-42-9.

[7] WISCHMEIER, W. H., SMITH, D. D. Predicting Rainfall Erosion Losses - A Guide Book to Conservation Planning. Washington: US. Dept. of Agriculture. Agr. Handbook, 1978, 537, 58 p.

[8] VAN OOST, K., GOVERS, G., DESMET, P. Evaluating the effects of changes in landscape structure on soil erosion by water and tillage. Landscape Ecology, 2000, 15, p. 577-589

[9] MERRITT, W. S., LETCHER, R. A., JAKEMAN, A. J. A review of erosion and sediment transport models. Environmental Modelling \& Software, 2003, 18, p. 761-799

[10] PANAgOS, P., IMESON, A., MEUSBURger, K., BORRELLI, P., POESEN, J., ALEWELL, CH. Soil Conservation in Europe: Wish or Reality? Land Degradation and Development, 2016, 27, p. 1547-1551

[11] SOBOTKOVÁ, V. Volumetrická kvantifikace projevư vodní eroze a jejich vliv na komplex vybraných půdních charakteristik. Disertační práce. Brno, 2012, $121 \mathrm{~s}$

[12] ŽížALA, D. KRÁSA, J. BÁČOVÁ, M. ZELENKOVÁ, K. LABURDA, T. NOVOTNÝ, I. Monitoring erozního poškozenípưdv ČRnástroji dálkového prüzkumuZemě. Praha: VÚMOP, 2016, 156 s. ISBN: 978-80-87361-63-4.

[13] AGISOFT. About. [on-line]. [citováno: 11.1. 2021]. Dostupné z: http://www.agisoft.com/
[14] SMITH, M. W. VERICAT, D. From experimental plots to experimental landscapes: topography, erosion and deposition in sub-humid badlands from Structure-from-Motion photogrammetry. Earth Surface Processes and Landforms, 2015, 40, p. 1656-1671

[15] CAROLLO, F. G., SI STEFANO, C., FERRO, V., PAMPALONE, V. Measuring rill erosion at plot scale by a drone-based technology. Hydrological Processes, 2015, 29, p. 3802-3811

[16] PETER, K. D., D'OLEIRE-OLTMANNS, S., RIES, J. B., MARZOLFF, I., AIT HSSAINE, A. Soil erosion in gully catchments affected by land-levelling measures in the Souss Basin, Morocco, analysed by rainfall simulation and UAV remote sensing data. Catena, 2014, 113, p. 24-40

[17] VÚMOP. eKatalog BPEJ. [on-line]. [citováno: 18. 1. 2021]. Dostupné z: https://bpej.vumop.cz/

[18] SONY Sony a6000. [on-line] [citováno: 3.2.2021]. Dostupné z: https://www.sony.com/electronics/ interchangeable-lens-cameras/ilce-6000-body-kit

[19] TRIMBLE. Geospatial. [on-line] [citováno: 3. 2. 2021]. Dostupné z: https://geospatial.trimble.com/ products-and-solutions/trimble-r2

[20] ESRI. ArcG/S. [on-line]. [citováno: 23. 1. 2021]. Dostupné z: https://www.esri.com/en-us/arcgis/ about-arcgis/overview

[21] HONZIKK, R., USŤAK, S., VACH, M. Hydropedologické parametry a objemová hmotnost pưd u variant dlouhodobých pokusů s rozdílnými způsoby zpracování. AgritechScience, 2016, 10, s. 1-7. ISSN 1802-8942.

[22] GLENDELL, M. et al. Testing the utility of structure from motion photogrammetry reconstructions using small unmanned aerial vehicles and ground photography to estimate the extent of upland soi erosion. Earth Surface Processes and Landforms, 2017, 42, p. 1860-1871

[23] SMITH, M. W., CARRIVICK, J. L., QUINCEY, D. J. Structure from motion photogrammetry in physical geography. Progress in Physical Geography, 2015, 40, p. 247-275

[24] DJI. Phantom 4 RTK. [on-line]. [citováno: 3. 2. 2021]. Dostupné z: https://www.dji.com/cz/ phantom-4-rtk?site=brandsite\&from =nav

\section{Autoři}

Mgr. Radek Bachan

凶radek.bachan@vuv.cz

ORCID: 0000-0002-9982-3132

Výzkumný ústav vodohospodářský T. G. Masaryka

Přispěvek prošel lektorským řízením.

DOI: 10.46555/VTEI.2021.03.004 


\section{QUANTIFICATION OF RILL EROSION USING CONTACTLESS METHODS}

\section{BACHAN, $\mathbf{R}$.}

T. G. Masaryk Water Research Institute

Keywords: contactless mapping - unmanned aerial system erosion quantification - aerial photogrammetry -

water erosion - torrential rainfall

In line with the rapid development of geoinformation and communication technologies, new possibilities are emerging for mapping and quantifying erosional processes caused by torrential rainfall. The quality, density and scope of input data are important to obtaining relevant results. The fast and relatively inexpensive collection of accurate geodata is enabled by unmanned aerial vehicles (UAV). The aerial images captured can be used to reconstruct the terrain morphology corresponding to the time of measurement using digital photogrammetry methods. The selected location affected by significant rill erosion was scanned in the monitoring campaign by an unmanned aerial system consisting of a TAROT 690 hexacopter and Sony Alpha 6000 camera. For subsequent topographical and altitudinal determination of the digital surface model (DSM), ground control points (GCP) were captured by a Trimble R2 GNSS rover. The total volume of eroded soil was set at $4274 \mathrm{~m}^{3}$. The deviations of the control points ranged in the first units of centimeters. The article describes the preparation and work in the field, contactless mapping of the area of interest, processing of the acquired data and the resulting calculation and quantification volume of the material carried away from the agricultural parcel damaged by the erosion. 